\title{
Use of anti-TNFs for difficult-to-treat urticaria: response to Cooke et al
}

\author{
This article was published in the following Dove Press journal: \\ Biologics: Targets and Therapy \\ 6 November 2015 \\ Number of times this article has been viewed
}

\author{
Simon Francis Thomsen ${ }^{1,2}$ \\ Freja Lærke Sand ${ }^{1,2}$ \\ 'Department of Dermatology, \\ Bispebjerg Hospital, Copenhagen, \\ Denmark; ${ }^{2}$ Department of Biomedical \\ Sciences, University of Copenhagen, \\ Copenhagen, Denmark
}

\section{Dear editor}

We read with interest the recent paper by Cooke et al about the use of biologic agents for intractable urticaria. ${ }^{1}$ Particularly, the authors reckon that the evidence supporting the use of anti-TNFs is limited by the small numbers of patients in non-controlled studies, often with urticarial disorders not typical of chronic urticaria such as vasculitis and delayed pressure urticaria. However, we want to draw the authors' and readers' attention to our report from 2013 about the use of adalimumab and etanercept in 20 patients with chronic urticaria with or without angioedema ${ }^{2}$ (updated in 2015 with an additional five patients). ${ }^{3}$ This report is to date the largest series of patients published and adds substantially to the small body of evidence supporting the use of anti-TNFs in subgroups of patients with chronic urticaria unresponsive to conventional therapy or omalizumab. Notably, $60 \%$ of our patients obtained complete or almost complete resolution of urticaria and angioedema after onset of therapy with either adalimumab or etanercept, whereas another $15 \%$ of our patients experienced partial response to therapy. Some of our patients were previously unresponsive to or experienced side effects from omalizumab. Duration of treatment ranged between 2 and 39 months. We observed side effects in $30 \%$ of our patients, particularly mild recurrent upper respiratory infections, whereas one patient experienced severe central nervous system toxicity. We propose that adalimumab and etanercept may be effective in some patients with chronic urticaria who do not respond sufficiently to high-dose antihistamines or in whom other immunosuppressive drugs or omalizumab are ineffective or associated with unacceptable side effects. However, patients should be monitored closely due to the possibility of severe side effects of anti-TNF treatment. We agree that larger randomized controlled trials are needed before a definite recommendation can be made in regards to the use of anti-TNFs for chronic urticaria.

\section{Disclosure}

The authors report no conflict of interest in this communication.

\section{References}

1. Cooke A, Bulkhi A, Casale TB. Role of biologics in intractable urticaria. Biologics. 2015;9:25-33

2. Sand FL, Thomsen SF. TNF-alpha inhibitors for chronic urticaria: experience in 20 patients. J Allergy (Cairo). 2013;2013:130905.

3. Sand FL, Thomsen SF. Off-label use of TNF-alpha inhibitors in a dermatological university department: retrospective evaluation of 118 patients. Dermatol Ther. 2015;28(3):158-165.

Fax $+45353|3| I 3$

Email simonfrancisthomsen@gmail.com

submit your manuscript | www.dovepress.con 
Dove Medical Press encourages responsible, free and frank academic debate. The content of the Biologics: Targets and Therapy 'letters to the editor' section does not necessarily represent the views of Dove Medical Press, its officers, agents, employees, related entities or the Biologics: Targets and Therapy editors. While all reasonable steps have been taken to confirm the content of each letter, Dove Medical Press accepts no liability in respect of the content of any letter, nor is it responsible for the content and accuracy of any letter to the editor.

Biologics: Targets \& Therapy

Dovepress

\section{Publish your work in this journal}

Biologics: Targets \& Therapy is an international, peer-reviewed journal focusing on the patho-physiological rationale for and clinical application of Biologic agents in the management of autoimmune diseases, cancers or other pathologies where a molecular target can be identified. This journal is indexed on PubMed Central, CAS, EMBase, Scopus

and the Elsevier Bibliographic databases. The manuscript management system is completely online and includes a very quick and fair peerreview system, which is all easy to use. Visit http://www.dovepress. com/testimonials.php to read real quotes from published authors.

Submit your manuscript here: http://www.dovepress.com/biologics-targets--therapy-journal 